\title{
Effect of smoking on Pulse Wave Velocity in different arterial segments
}

\author{
K. Singh
}

\begin{abstract}
Abstrak
Kecepatan gelombang nadi (Pulse wave velocity, PWV) diukur pada 25 subyek laki-laki bukan perokok dan dibandingkan dengan subyek perokok sebelum dan segera sesudah merokok. Tekanan darah, frekuensi nadi dan PWV tidak berbeda pada kedua kelompok sebelum merokok. Setelah merokok terjadi peningkatan tekanan darah, frekuensi nadi dan PWV pada segmen Aorta-Radialis (AoRad) dan Femoral-Dorsalis pedis (Fem-Dp), tapi pada segmen Aorta-Femoralis (Ao-Fem) terjadi penurunan PWV. Hal ini menunjukkan segmen arteri sentral dan perifer memberi respons yang berbeda terhadap merokok. (Med J Indones 2002; 11: 207-10)
\end{abstract}

\begin{abstract}
Pulse wave velocity $(P W V)$ was recorded in different arterial segments in 25 male nonsmokers and compared with age and sex matched smokers before and after smoking. Blood pressure (BP), Heart rate (HR) and PWV were comparable between nonsmokers and smokers before smoking. Just after cigarette smoking there was rise in HR, BP and PWV in Aorta to Radial (Ao-Rad), and femoral to Dorsalis Pedis (Fem-Dp) arterial segments, but the PWV was reduced in Aorta to Femoral (Ao-Fem) arterial segment, indicating that both peripheral and central arterial segments show different response to smoking. (Med J Indones 2002; 11: 207-10)
\end{abstract}

Keywords: smoking, pulse wave velocity

Pulse Wave Velocity (PWV) is directly related to arterial wall thickness and stiffness, ${ }^{1}$ and gives information about arterial function. ${ }^{2}$ Duration and number of cigarettes smoked per day are directly proportional to cardiac morbidity and mortality. ${ }^{3}$ Whole smoke, nicotine and carbon monoxide have been shown to damage the endothelium, resulting potentially atherogenic injury. ${ }^{2,4}$

The present study was conducted to evaluate the pulse wave velocity in central and peripheral segments of artery in normal, healthy non smokers and in smokers before and after cigarette smoking.

\section{METHODS}

PWV was recorded in 25 male smokers and compared with 25 matched normal healthy non smokers in regard to age (mean value in nonsmokers $31.6 \pm 9.17$ vs smokers $34 \pm 7.33$ years), sex and quetelet index (mean value in nonsmokers $2.29 \pm 0.34$ years smokers $2.22 \pm 0.37)$ A detailed history of smoking was

Department of Physiology, 9J-15, Medical Campus, Rohtak, Haryana, India gathered from each smokers with special reference to duration of smoking, number of bidi/cigarette smoked/day and age of starting of smoking. All the subjects were examined clinically to exclude any underlying cardiac disease. Subjects with haemoglobin level less than $10 \mathrm{gm} \%$ were excluded from the study. Subjects were asked to abstain from smoking 2 hours before the tests. Recording was done in the morning. Smoking of one cigarette (Red and White, Marcitch, non filter) was followed by smoking of another cigarette. Both the cigarette were finished within 10 minutes (range 5.2 to $7.5 \mathrm{~min}$, average $5.36 \mathrm{~min}$ ). Each cigarette was smoked to a butt length of $4.2 \mathrm{~cm}$ (total length $6.7 \mathrm{~cm}$ ). Data were collected in nonsmokers and in smokers before and after smoking.

\section{Segment studied}

Pulse wave velocity was recorded in the following arterial segments :

(a) From the root of the aorta to the left radial artery at the wrist (Ao-Rad).

(b) From the root of the aorta to the left femoral artery (Ao-Fem) just below the inguinal ligament.

(c) From the left femoral artery just below the inguinal ligament to the left dorsalis pedis artery (Fem-Dp). 


\section{Recording procedure}

The pulse wave at various points was recorded using pulse transducers having built in photodetectors and light sources. The subject was instructed to lie down in the supine position and the pulse transducers were placed and strapped in the following position: (i) over the femoral artery just below the inguinal ligament; (ii) over the left radial artery at the wrist; and (iii) over the dorsalis pedis artery. Simultaneous recordings of arterial pulse from the above mentioned sites, and of ECG, were made on a four channel polygraph (Polyrite $\mathrm{INCO}$ ) at a paper speed of $50 \mathrm{~mm} / \mathrm{sec}$ (Figure 1).

Figure 1. Diagrammatic representation of recordings of ECG, and of arterial pulse waves from radial, femoral and dorsalis pedis arteries.

\section{Measurements}

For arterial segments Ao-Rad and Ao-Fem, the time delay of the pulse wave was measured from the peak of the R-wave of the ECG to the beginning of the onset of the pulse wave in the radial artery and in the femoral artery respectively. In the case of segment Fem-Dp the PWV was obtained by measuring the time delay between the onset of pulse waves in the femoral and dorsalis pedis arteries. The time delay ( $\mathrm{t}$ ) of the pulse wave was measured using these points and was expressed in milliseconds. The length of the arterial segment (L) was measured on the surface of the body. The position of the root of the aorta was taken in the left third parasternal space. The PWV (meters/second) was calculated by using the formula $\mathrm{L} / \mathrm{t}$. In case of recordings using the R-wave of the ECG, a constant of $50 \mathrm{msec}$ was subtracted from the value to compensate for isovolumic contraction time. ${ }^{2}$ Only clearly defined tracings were analysed. In each subject five measurements were made for each segment and an average value was taken.

Heart rate (HR) was analysed by ECG. Blood pressure (BP) was recorded by sphygmomanometer. Data were analysed statistically using paired and unpaired ' $\mathrm{t}$ ' test.

\section{RESULTS}

Smokers had smoked 7 to 30 (mean $14.9 \pm 9.20$ ) beedis/cigarettes daily for 2 to 15 years (mean $10.66 \pm$ 5.92 years) from the age of $18.41 \pm 2.21$ years (mean). The HR, BP and PWV in different arterial segments were comparable among nonsmokers and smokers before smoking. In smokers, on cigarette smoking (i) basal HR and BP were increased significantly ( $<<0.001$ ), (ii) in peripheral arterial segment i.e. Ao-Rad and Fem-Dp, PWV showed significant increase ( $p<0.001)$, but (iii) in central segment i.e. Ao-Fem, PWV was reduced from $4.49 \pm 1.13$ to $3.46 \pm 1.10 \mathrm{msec}(\mathrm{p}<0.01)($ Table 1$)$.

Table 1. Heart rate, blood pressure and PWV (mean \pm SD) in various arterial segments in non-smokers and smokers (before and after smoking)

\begin{tabular}{llll}
\hline \multirow{2}{*}{ Parameters } & Nonsmokers & \multicolumn{2}{c}{ Smokers } \\
\cline { 3 - 4 } & & $\begin{array}{c}\text { Before } \\
\text { smoking }\end{array}$ & $\begin{array}{c}\text { After } \\
\text { smoking }\end{array}$ \\
\hline $\begin{array}{l}\text { Heart rate } \\
\text { (beats/min) }\end{array}$ & $74.42 \pm 15.17$ & $66.17 \pm 19.77$ & $83.58 \pm 9.69^{*}$ \\
Blood pressure: & & & \\
Systolic (mmHg) & $124.93 \pm 14.94$ & $120.0 \pm 11.0$ & $131.86 \pm 9.27^{*}$ \\
Diastolic (mmHg) & $76.93 \pm 12.84$ & $80.86 \pm 12.77$ & $91.06 \pm 10.57^{*}$ \\
PWV (m/sec) in & & & \\
arterial segment & & & \\
$\quad$ Ao-Rad & $5.81 \pm 1.12$ & $5.1 \pm 2.62$ & $8.45 \pm 3.15^{*}$ \\
Ao-Fem & $5.32 \pm 1.23$ & $4.49 \pm 2.13$ & $3.46 \pm 1.10^{*}$ \\
Fem-Dp & $7.03 \pm 1.13$ & $7.26 \pm 1.68$ & $8.80 \pm 2.76^{*}$ \\
\hline
\end{tabular}

$* \mathrm{p}<0.001$

\section{DISCUSSION}

Clinical criteria provide much information about vascular insufficiency but these are difficult to 
quantitate. HR and BP between nonsmokers and smokers before smoking are consistent with other reports. $^{5,6}$ PWV recorded in different arterial segments in normal healthy individuals agree fairly well with those reported earlier ${ }^{7}$ and it corresponds to PWV in smokers before smoking. On cigarette smoking, in smokers HR and BP were raised acutely which may be due to elevated sympathetic activity and decreased vagal restraints. ${ }^{8}$

Raised sympathetic activity and peripheral ischaemia ${ }^{3}$ caused by smoking may contribute to stiffening of arterial wall and thus raised PWV in peripheral arterial segments. On the contrary, central segment i.e. Ao-Fem showed less PWV in both the groups and was further decreased after smoking, which needs to be explored for its aetiopathophysiology.

It is concluded that peripheral and central arterial segments show different response to smoking.

\section{REFERENCES}

1. Nichols WW, Conti CR, Walker WW, et al. Input Impedence of systemic circulation in man. Circ Res 1977; 40:451-8.

2. Eliakim M, Sapoznikov D, Weinman J. Pulse Wave Velocity in healthy subjects and in patients with various disease states. Am Heart J 1971; 82: 448-57.

3. Holbrook JH. Nicotine addiction. In: Isselbacher KJ, Braunwald E, Wilson JD, Martin JB, Fauci AS, Karper DL editors. Harrison's principles of Internal medicine, $13^{\text {th }}$, vol 2, New York, McGraw-Hill Inc. 1998; p.2517.

4. Krupski WC. The peripheral vascular consequences of smoking. Ann Vasc Surg 1991; 5:291-304.

5. Gofin R, Kark JD, Fridlander Y. Cigarette smoking, blood pressure and pulse rate in the Jerusalum Lipid research. Clinic prevalence study. Isr J Med Sci 1982; 18: 1217.

6. Green MS, Jucha E, Luz Y. Blood pressure in smokers and nonsmokers: epidemiologic findings. Am Heart $\mathrm{J}$ 1986; 111 (5):932-40.

7. Rossman I. Clinical Geratrics, $2^{\text {nd }}$ ed. Philadelphia JB Lippincott Company. 1979, p.26.

8. Niedermaier N, Smith ML, Beightol LA, et al. Influence of cigarette smoking on human autonomic function. Circulation 1993; 88:562-71. 
